\title{
FIRST RECORD OF PYRRHALTA VIBURNI (COLEOPTERA: CHRYSOMELIDAE) IN BOSNIA AND HERZEGOVINA
}

\section{PRVI NALAZ VRSTE PYRRHALTA VIBURNI (COLEOPTERA: CHRYSOMELIDAE) U BOSNI I HERCEGOVINI}

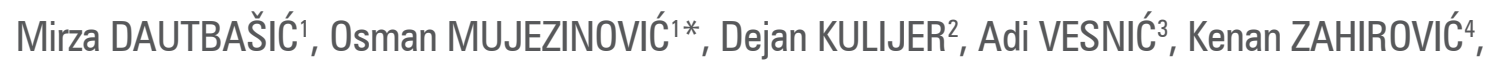 \\ Sead IVOJEVIĆ ${ }^{1}$, Damir PRLJAČA'
}

\begin{abstract}
SUMIMARY
Pyrrhalta viburni (Coleoptera: Chrysomelidae), is a chrysomelid native to Eurasia. It gained importance as an invasive species in North America due to its ability to cause serious damage to native and ornamental Viburnum spp. plants.

In our study Pyrrhalta viburni was recorded as a new record in the fauna of Bosnia and Herzegovina.

It has been recorded on four locations in Bosnia and Herzegovina in the region of Sarajevo. As it is feeding on $\mathrm{Vi}$ burnum spp. that are commonly used as ornamental plants, its monitoring in urban and other habitats is suggested.

KEY WORDS: Pyrrhalta viburni, viburnum leaf beetle, Viburnum spp., defoliation, Bosnia and Herzegovina.
\end{abstract}

\section{INTRODUCTION}

UVOD

Leaf beetles (Coleoptera: Chrysomelidae) is one of the most species-rich families of beetles with more than 37,000 species worldwide (Jolivet et al. 2011), and with the greatest diversity in the tropics (Riley et al. 2002). Leaf beetles are mostly phytophagous insects adapted to feed on plant species. Many leaf beetles are serious pests of agricultural crops and tree species (Jolivet et al. 1988).

In the Balkans the knowledge of Chrysomelidae is still scarce. Viktor Apfelbeck published the first significant data on Chrysomeliade fauna of Balkan Peninsula, particularly Bosnia and Herzegovina at the beginning of 20th century (Apfelbeck 1912; 1914; 1916). In later years several other papers were published, most significant for the country being Novak (1952) and Gruev (1979). In the most recent overviews Gruev (2005) listed 433 taxa for Bosnia and Herzegovina, while Löbl and Smetana (2010) reported 460 leaf beetle species for the country.

According to Gruev (2005), Löbl \& Smetana (2010) and de Jong et al. (2014) in the Balkans the species is reported from Croatia, Yugoslavia (Serbia and/or Montenegro) and Slovenia.

\footnotetext{
'Prof. dr. sc. Mirza Dautbašić, Faculty of Forestry, University of Sarajevo, Zagrebačka 20, 71000 Sarajevo, Bosnia and Herzegovina. E-mail: mirzad@bih.net.ba Prof. dr. sc. Osman Mujezinović, Faculty of Forestry, University of Sarajevo, Zagrebačka 20, 71000 Sarajevo, Bosnia and Herzegovina. E-mail: osmansfs@yahoo.com Doc. dr. sc. Sead Ivojević, Faculty of Forestry, University of Sarajevo, Zagrebačka 20, 71000 Sarajevo, Bosnia and Herzegovina. E-mail: sead_ivojevic@yahoo.com Mr Damir Prljača, Faculty of Forestry, University of Sarajevo, Zagrebačka 20, 71000 Sarajevo, Bosnia and Herzegovina. E-mail: prljacadamir1992@gmail.com

2 Dejan Kulijer, dipl. biolog, National Museum of Bosnia and Herzegovina, Zmaja od Bosne 3, 71000 Sarajevo, Bosnia and Herzegovina. E-mail: dejan.kuljer@gmail.com

${ }^{3}$ Doc. dr. sc. Adi Vesnić, Department of Biology, Faculty of Science, University of Sarajevo, Zmaja od Bosne 33-35, 71000 Sarajevo, Bosnia and Herzegovina. E-mail: vesnicadi@gmail.com

${ }^{4}$ Dr. sc. Kenan Zahirović, Public enterprise „Šumsko-privredno društvo Zeničko-dobojskog kantona“ d.o.o Zavidovići, Alije lzetbegovića 25, 72220 Zavidovići, Bosnia and Herzegovina. E-mail: zahirovic_kenan@yahoo.com

*Autor za korespodenciju (corresponding author)
} 
Pyrrhalta viburni is native to Europe and Asia, and has been introduced to North America (Becker 1979) where it is becoming an increasingly significant pest of plants from the genus Viburnum (Weston et al. 2008). Adults and larvae feed almost exclusively on species of viburnum with the strong preferences for European cranberrybush (Viburnum opulus L.) (Wheeler and Hoebeke 1994).

Adults of viburnum leaf beetle are approximately 4.5 to 6.5 $\mathrm{mm}$ in length, generally brown with the slightly dark anterior edge of elytra and dorsal surface covered with dense golden-grey hair. Larvae are greenish yellow with pattern of dark spots develops as they grow (Murray 2005; Weston and Hoebeke 2003a). Additional data regarding the biology and reproductive behavior can be found in Zorin (1931), Luhmann (1934), Weston et al. (2008) and Desurmont et al. (2009).

In this paper we report the first record of viburnum leaf beetle, Pyrrhalta viburni Paykull, 1799 in Bosnia and Herzegovina.

\section{MATERIALS AND METHODS MATERIJALI I METODE}

In May and June 2020 larvae of P. viburni were found at four locations in Bosnia and Herzegovina, near the city of the Sarajevo (Fig. 1). The second and third instar larvae of Pyrrhalta viburni were collected together with the host plant material of Viburnum spp. (Viburnum opulus L. from parks, localities 1 - 3 and semi - forest areas Viburnum lantana L. locality 4). Collected material has been brought to the entomological laboratory of the Faculty of Forestry, Sarajevo, Department for Forest Protection for further analysis. Several larvae were kept in the laboratory until adults fully developed. They were identified according to the morphological characteristics and keys from Becker (1979) and Wheeler and Hoebeke (1994).

Images of infested leaves and insects were taken with Nikon D7500 camera and detailed images of adults, pupa and larvae were taken under AF-S Micro NIKKOR 60 mm 1:2.8 GED. All samples are kept in Faculty of Forestry University of Sarajevo.

\section{RESULTS AND DISCUSSION REZULTATI I DISKUSIJA}

Our results show that this is the first record of viburnum leaf beetle, Pyrrhalta viburni in Bosnia and Herzegovina. Its presence was confirmed in all four inspected localities (Tab. 1).

Adults and larvae of P. viburni feed between the midrib and larger veins and skeletonize the leaves. Young larvae feed together on the underside of the young and tender leaves. Heavy infestations can cause defoliation, and plants continuously defoliated for two to three consecutive years may be killed (Young 2004).

Table 1. Localities of first record of Pyrrhalta viburni in Bosnia and Herzegovina Tablica 1. Lokaliteti prvog nalaza Pyrrhalta viburni u Bosni i Hercegovini

\begin{tabular}{cccc} 
Locality no. & Date - Datum & Locality, street - Lokalitet, ulica & Coordinates - Koordinate \\
\hline 1 & 18.05 .2020$. & Pazarić & $43^{\circ} 47^{\prime} 16^{\prime \prime} \mathrm{N} ; 18^{\circ} 07^{\prime} 56^{\prime \prime} \mathrm{E}$ \\
2 & 21.05 .2020$. & Sarajevo, Kolodvorska & $43^{\circ} 51^{\prime} 14^{\prime \prime} \mathrm{N} ; 18^{\circ} 23^{\prime} 14^{\prime \prime} \mathrm{E}$ \\
3 & 23.05 .2020$. & Sarajevo, Brčanska & $43^{\circ} 50^{\prime} 48^{\prime \prime} \mathrm{N} ; 18^{\circ} 22^{\prime} 01^{\prime \prime} \mathrm{E}$ \\
4 & 23.06 .2020$. & Breza, Trtorići & $44^{\circ} 02^{\prime} 15^{\prime \prime} \mathrm{N} ; 8^{\circ} 17^{\prime} 37^{\prime \prime} \mathrm{E}$
\end{tabular}
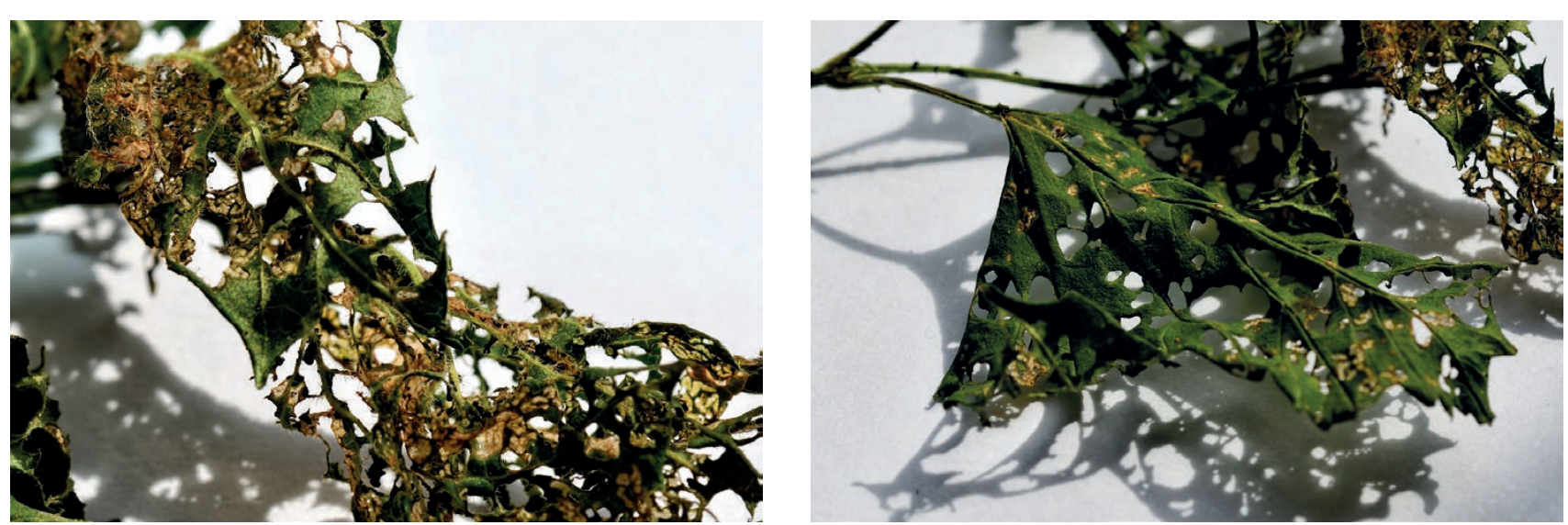

Figure 1. and Figure 2. Damage and defoliation of leaf caused by larvae (photo Mujezinović)

Fotografija 1. i 2. Oštećenje lisne površine i defolijacija biljke uzrokovana od Pyrrhalta viburni (foto Mujezinović) 


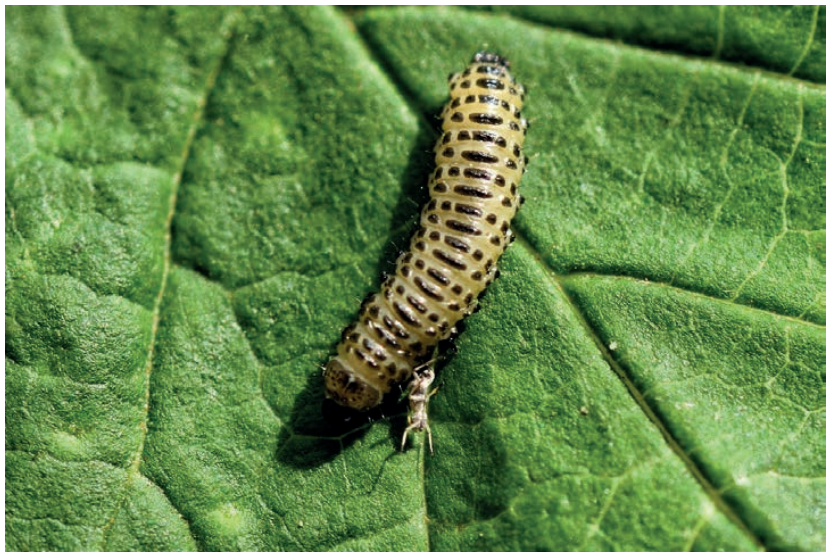

Figure 3. Third instar larvae of the viburnum leaf beetle, Pyrrhalta viburni (photo Mujezinović)

Fotografija 3. Treći razvojni stadij larve, Pyrrhalta viburni (foto Mujezinović)

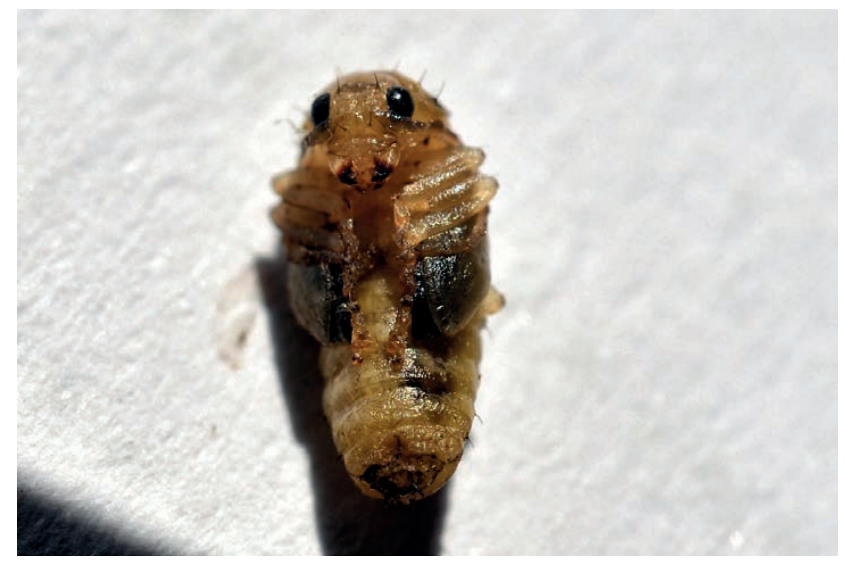

Figure 4. Pupa of the viburnum leaf beetle, Pyrrhalta viburni (photo Mujezinović)

Fotografija 4. Razvojni stadij lutke Pyrrhalta viburni (foto Mujezinović)

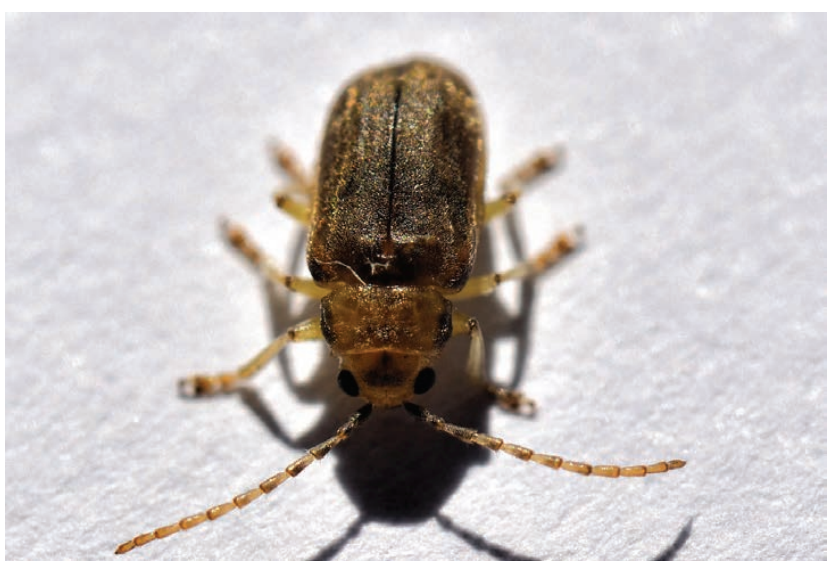

Figure 5. Adult of the viburnum leaf beetle, Pyrrhalta viburni (photo Mujezinović)

Fotografija 5. Imago Pyrrhalta viburni (foto Mujezinović)

Newly hatched larva is greenish yellow and very small about 1-2 mm. Mature larva is $10-11 \mathrm{~mm}$ long and sub-cylindrical (Fig. 3).
The pupa of the viburnum leaf beetle is approximately 3.5 to $4.5 \mathrm{~mm}$ in length (Fig. 4).

The viburnum leaf beetle is approximately 4.5 to $6.5 \mathrm{~mm}$ in length (Fig. 5).

It is strongly suggested to continue the monitoring of this insect on Viburnum spp. in Bosnia and Herzegovina and to estimate its potential of becoming an pest that could endanger ornamental and other values of its hosts. The hosts plants of this beelte play an important role for horticulture in parks and element of diversity and stability of forest ecosystems. As the species does not have its local (Bosnian) name, we suggest it to be "hudikina zlatica", as "hudika" is a common name for Viburnum spp. in Bosnia and Herzegovina and "zlatica" is commonly used name for members of Chrysomelidae family.

\section{REFERENCES} LITERATURA

- Apfelbeck, V., 1912: Komponente balkanske faune iz roda Chrysomelidae (Col.). - Glasnik Zemal. Muz. Bosn. Herzeg., 24: 235-263

- Apfelbeck, V., 1914: Komponente balkanske faune iz roda Chrysomelidae (Col.). - Glasnik Zemal. Muz. Bosn. Herzeg.,26: 435-450

- Apfelbeck, V., 1916: Komponenten der Balkanfauna aus der Familie Chrysomelidae (Col.). - Wiss. Mitteil. Bosn. Hezwg., 13: $354-396$

- Becker EC., (1979): Pyrrhalta viburni (Coleoptera: Chrysomelidae), a Eurasian pest of Viburnum recently established in Canada. The Canadian Entomologist 111: 417-419.

- Desurmont, G. A., Fritzen, C. M., \& Weston, P. A. 2009: Oviposition by Pyrrhalta viburni (Paykull) on dead plant material: successful reproductive strategy or maladaptive behavior?. In Research on Chrysomelidae, Volume 2 (pp. 119-130). Brill.

- de Jong, Y. et al. (2014) Fauna Europaea - all European animal species on the web. Biodiversity Data Journal 2: e4034. doi: 10.3897/BDJ.2.e4034.

- Gruev, B. A., 1979: Chrysomelidae (Coleoptera) Jugoslawiens (Unterfamilien: Lamprosomatinae, Eumolpinae, Chrysomelinae, Alticinae, Hispinae, Cassidinae). Dtsch. ent. Z., N. F. 26, 1-3: 113-152

- Gruev, B. A. 2005: A comparative list of the leaf beetles of the Balkan countries (Coleoptera: Chrysomelidae). Animalia 41: 23-46.

- Jolivet, E, P., Petitpierre, E., and Hsiao, T. 1988: Biology of Chrysomelidae. Series Entomologica. Kluwer Academic Publishers, Dordrecht.

- Jolivet, P., Santiago-Blay, J. A. \& Schmitt, M. (eds.) 2011: Research on Chrysomelidae 3. ZooKeys 157 (special issue), Pensoft Publishers, Sofia-Moscow, pp. 179.

- Löbl, I., Smetana, A. (Eds.), 2010: Catalogue of Palearctic Coleoptera, Volume 6, Chrysomeloidea. Apollo Books, Stenstrup.

- Lühmann, M., 1934: Bietrag zur Biologie des Schnee- ballkäfers Gallerucella viburni Payk. Z. Angew. Entomol. 20: 531-564. 
- Murray T. 2005: Pest Alert! The Viburnum Leaf Beetle. Garden Friends and Foes. Washington State University. http://whatcom. wsu.edu/ag/homehort/pest/VLB.htm (13 January 2006).

- Novak, P., 1952: Kornjaši Jadranskog primorja. - Izd. Zavod Jugosl. Akad. Znanosti. 521

- Riley, E., Clark, S., Flowers, R., and Gilbert, A., 2002: Chrysomelidae Latreille 1802. In Arnett, R., Thomas, M., Skelley, P., and Frank, J., editors, American Beetles: Polyphaga: Scarabaeoidea through Curculionoidea. Vol. 2., pages 617-691. CRC Press.

- Weston PA, Hoebeke ER., 2003a: Viburnum leaf beetle, Pyrrhalta viburni (Paykull) (Coleoptera: Chrysomelidae): Dispersal pattern of a palearctic landscape pest in New York and its distribution status in the northeastern U.S. and eastern Canada. Proceedings of Entomological Society of Washington 105: 889-895.
- Weston, P. A., Diaz, M. D., \& Desurmont, G. A. 2008: Ovipositional biology of Viburnum leaf beetle, Pyrrhalta viburni (Coleoptera: Chrysomelidae). Environmental entomology, 37(2), 520-524.

- Wheeler AG Jr., Hoebeke ER.. 1994: First records from the Canadian Maritime Provinces of three European insects injurious to ornamental plants. Proceedings of Entomological Society of Washington 96: 749-756.

- Zorin, P. V.. 1931: Guelder rose leaf-beetle (Galerucella viburni Payk.). Bull. Inst. Controlling Pests Dis, 1, 55-79.

- Young CE., 2004: Ornamental Plants Annual Reports and Research Reviews 2004. Bulletin, Extension and Research. The Ohio State University.

\section{SAŽETAK}

Pyrrhalta viburni (Coleoptera: Chrysomelidae), hudikina zlatica je kornjaš autohton u Europi i Aziji. U Sjevernoj Americi hudikina zlatica je invazivna, zbog čega je porastao interes za istraživanje biologije vrste. Imaga i ličinke hrane se najčešće lišćem biljaka iz roda Viburnum i uzrokuju štete na listovima, a zbog tendencije da agregiraju i polažu jaja na već oštećenim biljkama izazivaju oštećenja koja mogu uzrokovati sušenja biljke. Odrasli oblici su 4,5-6,5 mm duge, smeđe boje sa blago tamnijim prednjim dijelom elitri, dok je dorzalna površina prekrivena sa gustim zlatno-sivim dlačicama.

Imaga i ličinke sakupljene su od 18.05. do 23.06.2020. godine na četiri lokaliteta: Pazarić, dva lokaliteta u urbanom području grada Sarajeva (ulice Kolodvorska i Brčanska) i Trtorići (Općina Breza).

Ovo je prvi nalaz ove vrste kukca, potencijalno važnog defolijatora autohtonih i kultiviranih vrsta iz roda Viburnum koji ukazuje na potrebu daljeg istraživanja rasprostranjenosti i brojnosti vrste Pyrrhalta viburni na području Bosne i Hercegovine. 